Original article

https://www.journal-imab-bg.org

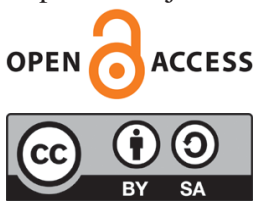

\title{
MOTHERS' KNOWLEDGE TOWARDS ORAL HEALTH OF CHILDREN AGED UP TO 3 YEARS BEFORE AND AFTER EDUCATIONAL PRO- GRAM
}

\author{
Ralitsa Bogovska-Gigova, Rositza Kabaktchieva \\ Department of Pediatric Dentistry, Faculty of Dental Medicine, Medical Uni- \\ versity, Sofia, Bulgaria.
}

\section{ABSTRACT:}

Purpose: To comparatively analyze the oral healthrelated knowledge of mothers of children aged up to 3 years before and after the "Dental Home for Children" educational program (www.dentalendom.bg)

Material/methods: The study involved a group of 90 mothers of children aged up to 3 years who visited the special educational and motivational website www.dentalendom.bg and completed our survey. We compared and processed the results of the survey using 90 control questionnaires, which were completed by parents who had visited the dental office without having attended an oral health education and motivation session in advance.

Results: The results obtained from the survey completed by mothers of children aged up to 3 years show that their knowledge of the importance of fluoride prevention, the risks of nighttime bottle feeding with baby formula for a long time, mistakes in feeding, and the early transmission of cariogenic bacteria increased substantially compared to the mothers who did not visit the educational website.

Conclusion: The obtained positive results give us reason to believe that e-learning health education programs are useful for both mothers and children aged up to 3 years. motion,

Keywords: dental home, motivation, oral health pro-

\section{INTRODUCTION:}

Oral health is an important component of overall human health and must be maintained throughout life [1]. Public awareness of oral diseases is essential to prevention [2]. The knowledge of parents/children varied, depending on the different levels of education, sociîeconomic status, interest, access to information, and other characteristics [2]. Respectively, oral health care depends on the level of parents' awareness and knowledge. In this context, patient knowledge assessment programs play a crucial role.

Early Childhood Caries (ECC) is defined as the presence of one or several carious, missing, or filled primary teeth in children up to the age of 71 months [3]. ECC is a multi-factor disease resulting from the interaction of cariogenic bacteria, carbohydrates, dietary practices, and socî̂economic factors [4]. Clinicians believe that an essen- tial step to ECC management is that children at high risk of developing caries are identified early. Prevention of ECC can be achieved with the aid of anticipatory guidance, diet counseling, educating parents regarding decay promoting feeding behaviors, maintain good oral hygiene, and the use of preventive agents as fluoride. Establishing a Dental Home before the child reaches the age of 1 is also recommended [5]. Oral care education and training are integral components of caries prevention programs. Babies and young children are unable to take care of themselves and are fully dependent on their parents. Studies show that the knowledge of mothers is very important and has a strong impact on the oral health of their children $[6,7]$. Therefore, the measures recommended by AAPD advise that a Dental Home is established within the first six months after the eruption of the first tooth and that parents are trained in the prevention of oral cavity diseases [5].

In the last 20 years, we brought the rapid advent of digital technologies into daily life. Today, the internet is essential to how we communicate, shop, travel, and manage our resources. This new reality has prompted us to develop and promote our educational and motivational program "Dental Home for Children" [8]. The program will serve as an electronic platform for raising the awareness and knowledge of mothers of the oral health of their children. We expect that the information will inspire a change in mothers' behavior to achieve better oral health outcomes for their children.

\section{PURPOSE:}

To create a comparative analysis of the knowledge of mothers of children aged up to 3 years towards oral health care before and after the "Dental Home for Children" educational program (www.dentalendom.bg)

\section{MATERIALS AND METHODS:}

The mothers of young children were invited via Facebook to visit the specialist website we created, www.dentalendom.bg. Our program includes 24 topical health articles, 8 motivational modules (on dental caries etiology, feeding, and oral hygiene), 2 games (on oral hygiene and healthy foods for the teeth), and other educational materials on topics relating to early dental prevention. We explained to the 
respondents that on the webpage, they would have access to the educational materials and the survey containing 12 questions in a dedicated section of the website. After familiarizing themselves with our website, they could fill out the surveys available. In 3 months (July-September 2020), the survey was completed by 191 mothers, of which we randomly selected 90 surveys. We thus selected the group of mothers who had attended our "Dental Home for Children" program, which is referred to as the experimental group below. The answers to the survey questions of experimental group respondents were compared to those in the surveys completed by 90 other mothers from the control group of mothers of children aged up to 3 years who had visited our dental office for dental examinations of their young children. The registered answers of the mothers were statistically processed using SPSS (version 19, SPSS Inc., USA. For a level of significance for which the zero hypothesis is rejected, we choose a $95 \%$ confidence level $(\mathrm{p}<0.05)$.

\section{RESULTS:}

The results of the comparative analysis of the answers given by mothers of children aged up to 3 years in the two groups (experimental and control), respectively with and without attending the "Dental Home for Children" educational program in advance (www.dentalendom.bg) are set out in the tables and graphics below.

Table 1. Relative share of the answers to Question 1 in the survey by the mothers in the two main groups

\begin{tabular}{|c|c|c|c|c|c|c|c|c|c|c|}
\hline Question 1 & \multicolumn{10}{|c|}{ During your pregnancy have you received advice on dental prophylaxis for your baby? } \\
\hline \multirow[t]{2}{*}{$\begin{array}{l}\text { Answer } \\
\text { Group }\end{array}$} & \multicolumn{2}{|l|}{ No } & \multicolumn{2}{|c|}{$\begin{array}{l}\text { Yes, from a } \\
\text { gynecologist }\end{array}$} & \multicolumn{2}{|c|}{$\begin{array}{l}\text { Yes, from a } \\
\text { dentist }\end{array}$} & \multicolumn{2}{|c|}{$\begin{array}{l}\text { Yes, from work- } \\
\text { shops/ courses } \\
\text { for pregnant } \\
\text { women }\end{array}$} & \multicolumn{2}{|c|}{$\begin{array}{l}\text { Yes, from a } \\
\text { pediatrician/ } \\
\text { general practi- } \\
\text { tioner }\end{array}$} \\
\hline & $\mathrm{n}$ & $\%+/-\mathrm{sp}$ & $\mathrm{n}$ & $\%+/-\mathrm{sp}$ & $\mathrm{n}$ & $\%+/-\mathrm{sp}$ & $\mathrm{n}$ & $\%+/-\mathrm{sp}$ & $\mathrm{n}$ & $\%+/-\mathrm{sp}$ \\
\hline Experimental group & $76(1)$ & $84.44+/-3.82$ & 2 & $2.22+/-1.55$ & 7 & $7.8+/-2.82$ & 2 & $2.22+/-1.55$ & 3 & $3.33+/-1.89$ \\
\hline Control group & $82(2)$ & $91.11+/-3.00$ & 3 & $3.33+/-1.89$ & 1 & $1.11+/-1.10$ & 4 & $4.44+/-2.17$ & 0 & 0 \\
\hline$t$-test & & \multicolumn{9}{|c|}{$\mathrm{T}_{1,2}=1.37, \mathrm{p}_{1,2}>0.05$} \\
\hline
\end{tabular}

When comparing the data for the two groups of surveyed mothers, we see that in both groups, we have a higher share of mothers who did not receive any oral health prophylaxis advice during their pregnancy. The mothers from the experimental group gave a positive answer to the question of whether they received pertinent medical information promptly. These are mothers who had an early awareness of the importance of prophylaxis for the oral health of their children and were prone to seeking information from a variety of sources, including our website. We also had a high number of mothers who were not instructed or referred to early oral prophylaxis but sought and responded to the information available in the framework of the training program on our website.

Table 2. Relative share of the answers to Question 2 in the survey by the mothers in the two main groups.

\begin{tabular}{|c|c|c|c|c|c|}
\hline Question 2 & \multicolumn{5}{|c|}{$\begin{array}{l}\text { Did you attend an examination/receive a consultation from a dental physician on } \\
\text { the oral health care of your baby during pregnancy? }\end{array}$} \\
\hline Answer Group & \multicolumn{2}{|l|}{ No } & \multicolumn{2}{|l|}{ Yes } & \multirow[t]{2}{*}{ t-test } \\
\hline Experimental group & $\mathrm{n}$ & $\%+/-\mathrm{sp}$ & $\mathrm{n}$ & $\%+/-\mathrm{sp}$ & \\
\hline $0-1$ year & 26 & $86.67+/-6.21$ & 4 & $13.33+/-6.21$ & $\mathrm{~T}=8.36 \mathrm{p}<0.05$ \\
\hline $1-2$ years & 25 & $83.33+/-6.80$ & 5 & $16.67+/-6.80$ & $\mathrm{~T}=6.93 \mathrm{p}<0.05$ \\
\hline $2-3$ years & 20 & $66.67+/-8.61$ & 10 & $33.33+/-8.61$ & $\mathrm{~T}=2.74 \mathrm{p}<0.05$ \\
\hline Total & $\underline{71}$ & $\underline{78.89+/-4.30}$ & $\underline{19}$ & $\underline{21.11+/-4.30}$ & $\mathrm{~T}=13.46 \mathrm{p}<0.05$ \\
\hline Control group & & & & & \\
\hline $0-1$ year & 29 & $96.67+/-3.28$ & 1 & $3.33+/-3.28$ & $\mathrm{~T}=20.14 \mathrm{p}<0.05$ \\
\hline $1-2$ years & 28 & $93.33+/-4.55$ & 2 & $6.67+/-4.55$ & $\mathrm{~T}=13.46 \mathrm{p}<0.05$ \\
\hline $2-3$ years & 28 & $93.33+/-4.55$ & 2 & $6.67+/-4.55$ & $\mathrm{~T}=13.46 \mathrm{p}<0.05$ \\
\hline Total & $\underline{85}$ & $93.77+/-4.12$ & $\underline{5}$ & $\underline{5.55+/-4.12}$ & $\mathrm{~T}=26.03 \mathrm{p}<0.05$ \\
\hline
\end{tabular}

The results show that in total, the mothers from the experimental group, which were consulted by a dental practitioner $(21 \%)$ on the oral health of their young child, were significantly more (by approximately $15 \%$ ) compared to the mothers in the control group who gave the same answer
$(5.5 \%)$. This is probably because mothers who are better educated in matters relating to oral health are more motivated to seek care for their children. It should be noted that a large percentage of mothers did not seek a consultation / attend a check-up with a dentist during pregnancy $-78 \%$ of the 
mothers in the experimental group and $94 \%$ of mothers in the control group $(\mathrm{t}=3.15, \mathrm{p}<0.05)$.

The data set out in Table 3 presents the answers of the mothers from the two groups in respect of their knowl- edge and the opportunities they had until the survey to set up a Dental Home or visit a pediatric dentist who takes care of the oral health of their children.

Table 3. Relative share of the answers to Question 3 in the survey by the mothers in the two main groups

\begin{tabular}{|l|c|l|l|l|l|l|}
\hline Question & \multicolumn{4}{l|}{$\begin{array}{l}\text { Does your child have an established Dental Home or access to a pediatric } \\
\text { dentist who takes care of the child's oral health needs? }\end{array}$} \\
\hline AnswerGroups & \multicolumn{2}{|l|}{ No } & \multicolumn{2}{l|}{ Yes } & \multicolumn{1}{l|}{$\begin{array}{l}\text { I did not know this is } \\
\text { important }\end{array}$} \\
\hline & & $\mathrm{n}$ & $\%+/$ - sp & $\mathrm{n}$ & $\%+/-\mathrm{sp}$ \\
\hline Experimental group & 52 & $57.78+/-5.21$ & 20 & $22.22+/-4.38$ & 18 & $20.00+/-4.22$ \\
\hline Control group & 62 & $68.89+/-4.88$ & 14 & $15.56+/-3.82$ & 14 & $15.56+/-3.82$ \\
\hline t-test & & $\mathrm{T}=1.56 \mathrm{p}>0.05$ & & $\mathrm{~T}=1.15 \mathrm{p}>0.05$ & $\mathrm{~T}=0.78 \mathrm{p}>0.05$ \\
\hline
\end{tabular}

The answers show that there are no verifiable differences in the mothers from the two groups in terms of the number of those whose children have an established Dental Home $(p>0,05)$ and that their percentage is small $22 \%$ of children in the experimental group and $15.5 \%$ of the children in the control group.

Mothers' answers about the impact of eating habits on the oral health of their children are included in the next three graphics.

Graph. 1. Relative share of the answers to Question 4 in the survey by the mothers in the two main groups

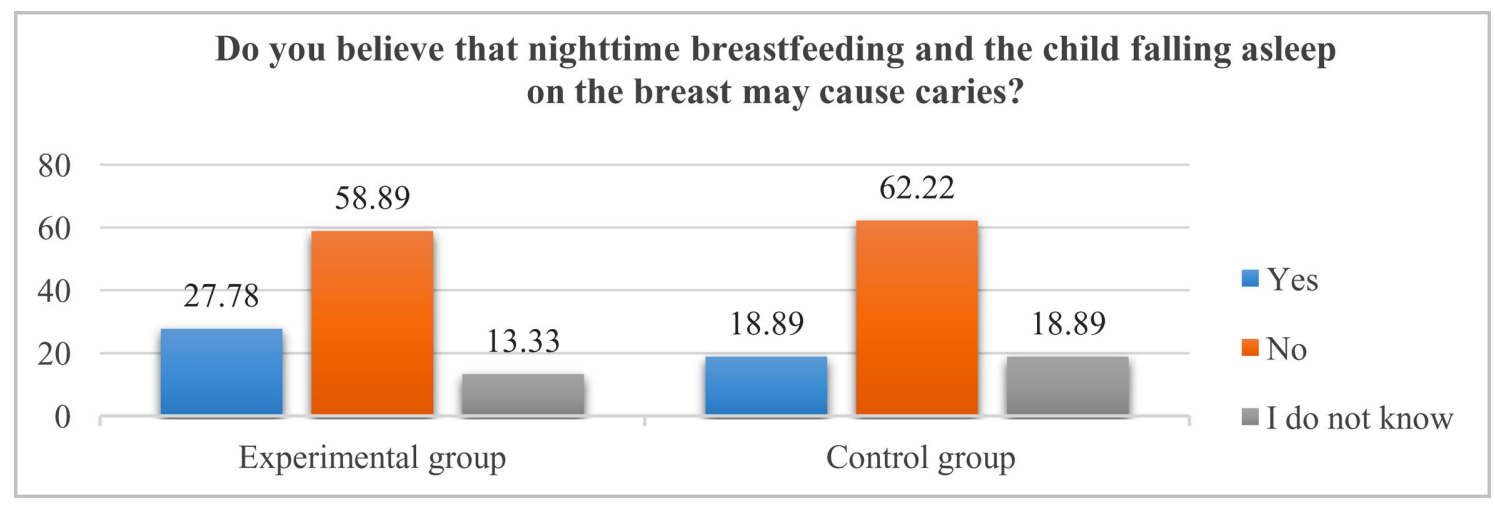

Only approximately $28 \%$ of the mothers who attended the training program and approximately $19 \%$ of those in the control group were aware that nighttime feeding might cause caries $(T=1.42, \mathrm{p}>0.05)$. The materials on our website are based on world guidelines and contain a wealth of breastfeeding advice. The World Health Organization (WHO) recommends breastfeeding solely and exclusively during the first 6 months of a child's life, followed up by a combination of breastfeeding and another suitable food until the child reaches the age of 2 years [9].

Graph. 2. Relative share of the answers to Question 5 in the survey by the mothers in the two main groups

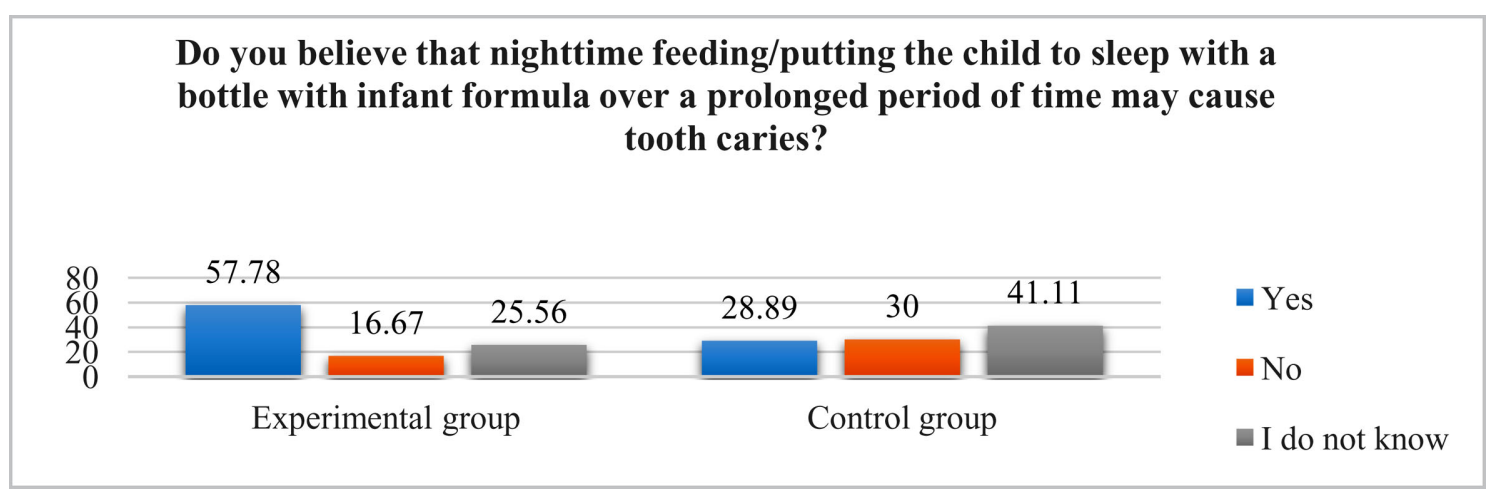


Approximately $58 \%$ of the mothers from the experimental group demonstrate a solid knowledge of the negative impact of this practice on the oral health of young children as compared to $29 \%$ of mothers in the control group $(\mathrm{p}<0.05)$. The relative share of mothers in the experimen- tal group who were not aware or did not know that nighttime feeding / allowing the child to fall asleep with a bottle with infant formula places the child at risk of ECC remains high (approximately 42\%).

Graph. 3. Relative share of the answers given by the respondents in the two main groups to Question 6.

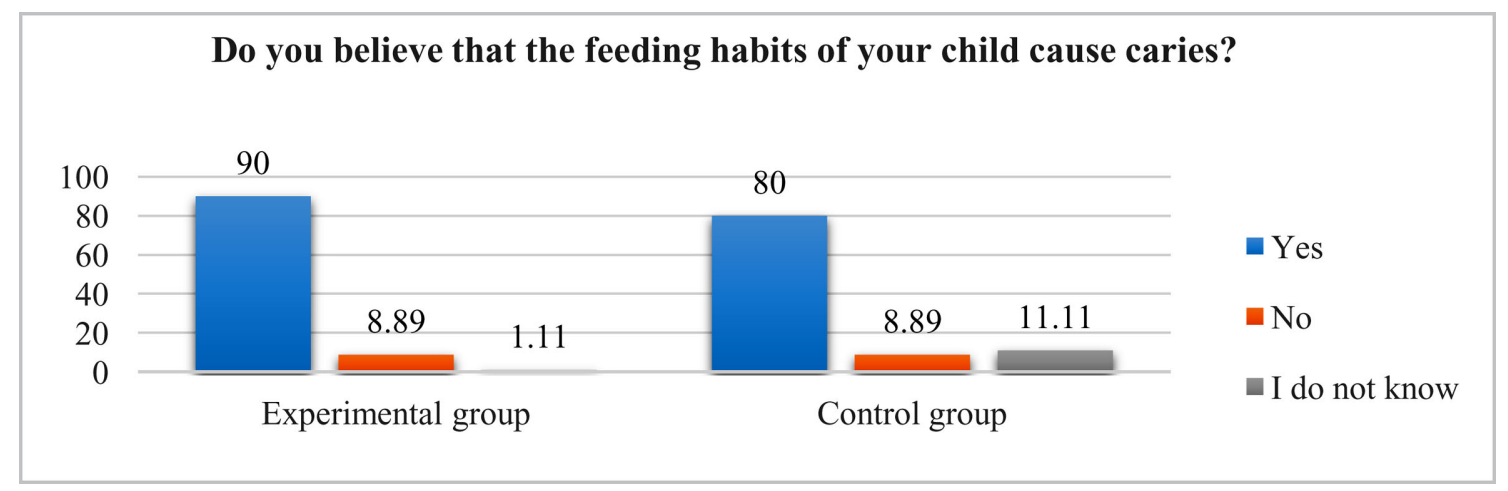

The answers to the question of whether mistakes in dietary habits are a risk factor for the development of caries gave the following results: the largest share $(90 \%)$ of the mothers from the experimental group gave a positive answer to the question. This is $10 \%$ more than the mothers who gave the same answer in the control group $(\mathrm{T}=1.90$, $\mathrm{p}<0.05)$. Only $8 \%$ of mothers in both control groups did not believe that feeding may be a risk factor for the development of caries. The share of mothers who did not know that inappropriate feeding practice can prolong the exposure of teeth to fermentable carbohydrates and lead to caries was relatively small in the experimental group (1\%) as compared to the control group $(11 \%)(\mathrm{T}=2.86, \mathrm{p}<0,05)$.

Graph. 4. Relative share of the answers given by the respondents in the two main groups to Question 7

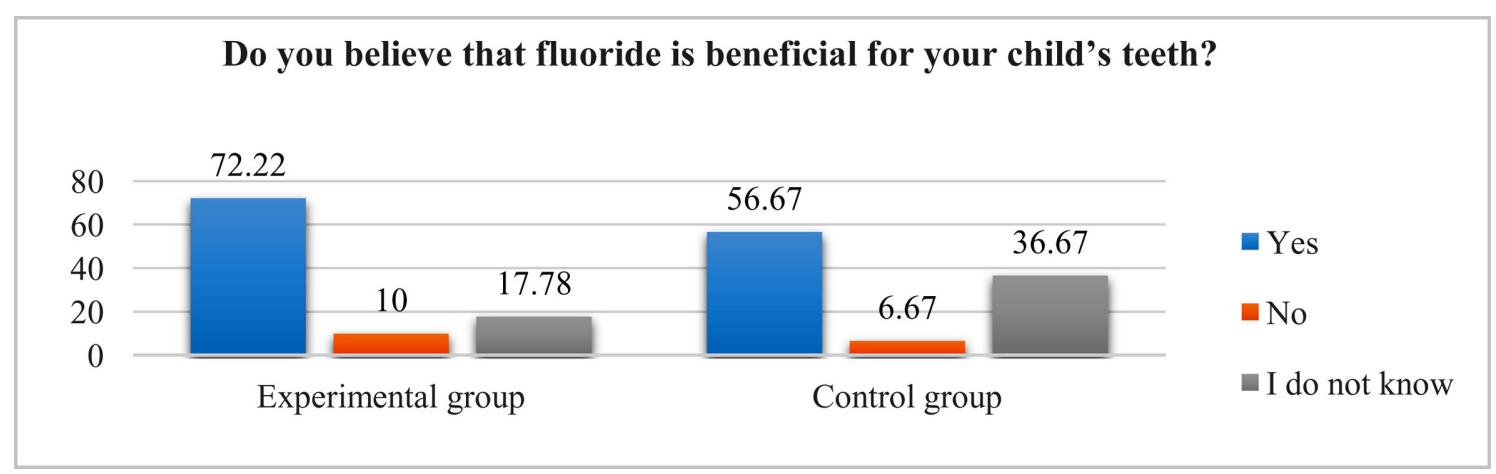

Data shows that $72 \%$ of the mothers in the experimental group gave a positive answer to whether fluoride is effective in preventing dental caries, which is $15 \%$ higher than the number of mothers who gave the same answer in the control group. These results are supported by statistically significant differences $(\mathrm{T}=2.21, \mathrm{p}<0.05)$. The per- centage of mothers who do not believe that fluoride is beneficial is relatively low in both groups (below 10\%). It is clear that in the experimental group, the share of mothers who do not know whether fluoride is beneficial (approximately 18\%) is twice lower than the share of mothers in the control group (approximately 37\%) $(\mathrm{T}=2.91, \mathrm{p}<0.05)$.

Table 4. Relative share of the answers given by the respondents in the two main groups to Question 8

\begin{tabular}{|l|c|c|c|c|c|}
\hline Question 8 & \multicolumn{5}{|c|}{ Have you heard about Early Childhood Caries (ECC)? } \\
\cline { 1 - 5 } Answer Group & \multicolumn{2}{|c|}{ No } & \multicolumn{2}{|c|}{ Yes } & \\
\hline Experimental group & $\mathrm{n}$ & $\%+/-\mathrm{sp}$ & $\mathrm{n}$ & $\%+/-\mathrm{sp}$ & $\mathrm{T}=1.04 \mathrm{p}>0.05$ \\
O-1 year & 17 & $56.67+/-9.05$ & 13 & $43.33+/-9.05$ & $\mathrm{~T}=3.38 \mathrm{p}<0.05$ \\
$1-2$ years & 21 & $70.00+/-8.37$ & 0 & $30.00+/-8.37$ & $\mathrm{~T}=2.74 \mathrm{p}<0.05$ \\
$2-3$ years & 20 & $66.67+/-8.61$ & 10 & $33.33+/-8.61$ & $\mathrm{~T}=4.05 \mathrm{p}<0.05$ \\
\cline { 2 - 5 } Total & $\underline{58}$ & $\underline{64.44+/-5.05}$ & $\underline{32}$ & $\underline{35.56+/-5.05}$ & \\
\hline
\end{tabular}




\begin{tabular}{|l|c|c|c|c|l|}
\hline Control group & & & & \\
$0-1$ year & 23 & $76.67+/-7.72$ & 7 & $23.33+/-7.72$ & $\mathrm{~T}=4.88 \mathrm{p}<0.05$ \\
$1-2$ years & 27 & $90.00+/-5.48$ & 3 & $10.00+/-5.48$ & $\mathrm{~T}=10.33 \mathrm{p}<0.05$ \\
$2-3$ years & 20 & $66.67+/-8.61$ & 10 & $33.33+/-8.61$ & $\mathrm{~T}=2.74 \mathrm{p}<0.05$ \\
$\underline{\text { Total }}$ & $\underline{70}$ & $\underline{78.89+/-4.38}$ & $\underline{20}$ & $\underline{21.11+/-4.38}$ & $\mathrm{~T}=8.96 \mathrm{p}<0.05$ \\
\hline
\end{tabular}

The answers to the above question clearly show that only $21 \%$ of the mothers from the control group had heard about ECC. In the experimental group, this share is slightly higher $(35 \%)$, but the difference is statistically significant $(\mathrm{T}=2.00, \mathrm{p}<0.05)$. In the different age groups, there were no statistically significant differences between the number of mothers in the two groups who did not know or had not heard about early childhood caries. The same applies to the groups which had heard about the disease $(p>0.05)$. The largest number of women who were familiar with early childhood caries (approximately 33\%) were the mothers of children in the third age group ( 2 to 3 years age) in both groups. The share of mothers who admitted to not being familiar with ECC was very high in both groups (64\% in the experimental group and $79 \%$ in the control group).

Graph. 5. Relative share of the answers to Question 9 in the survey by the mothers in the two main groups

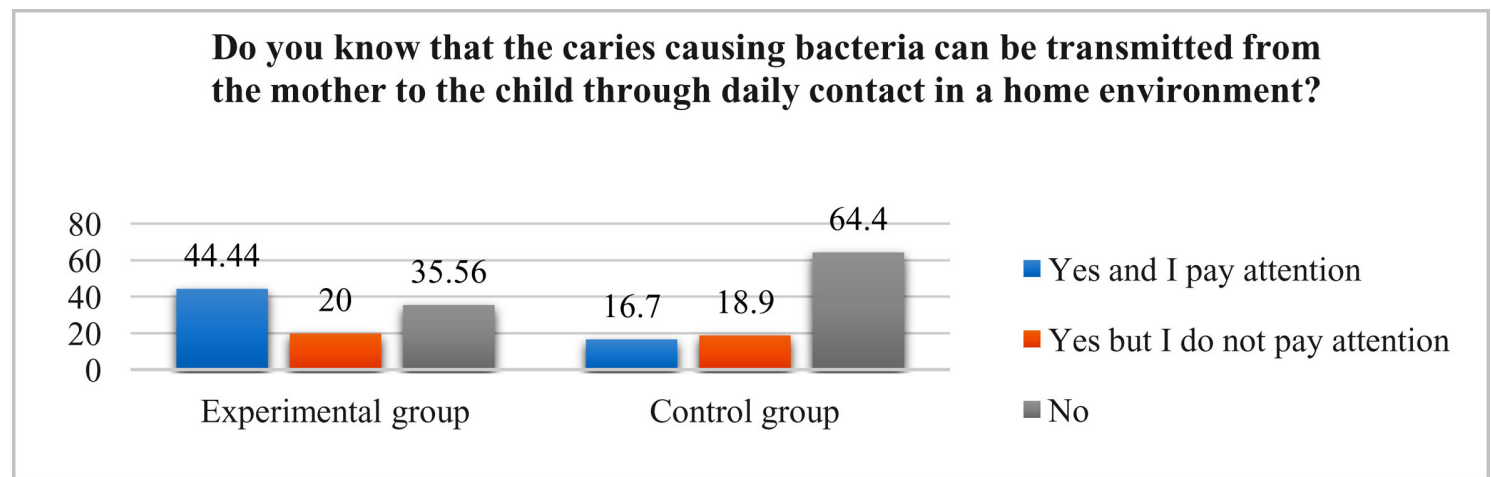

The graphic shows that the share of mothers from the control group who did not know that they can transmit bacteria to their children, causing caries was high $(64 \%)$. In the experimental group, we established that the relative share of mothers who gave a negative answer to the ques- tion was twice lower (only $35 \%-\mathrm{T}=4.05, \mathrm{P}<0.05$ ). Respectively, the share of mothers from the experimental group who were aware and took care of the transmission of caries causing bacteria was significantly higher in the experimental group $(\mathrm{T}=4.24, \mathrm{P}<0.05)$.

Graph. 6. Relative share of the answers to Question 10 in the survey by the mothers in the two main groups

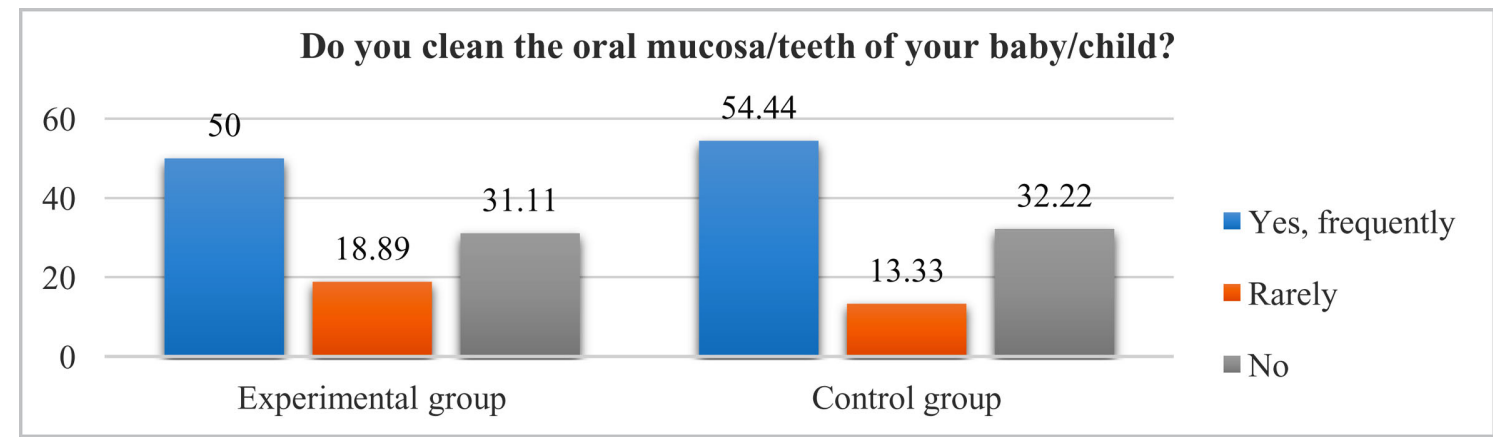

More than $50 \%$ of the mothers in both answered that they regularly clean the oral cavity of their baby or toddler. The remaining $50 \%$ of respondents said that 'they do not regularly clean' or 'do not clean at all' the oral cavity of their child. The statistical analysis of data did not reveal any significant differences $(\mathrm{T}=0.60, \mathrm{P}>0.05)$.

We asked the mothers from the experimental group two additional questions. 
Table 5 Relative share of the answers to Question 11 given by the mothers in the experimental group

\begin{tabular}{|c|c|c|c|c|c|c|c|c|c|}
\hline \multicolumn{10}{|c|}{ When, in your opinion, do you have to take your child to the dentist? } \\
\hline \multicolumn{2}{|c|}{$\begin{array}{l}\text { Before it reaches } \\
\text { the age of } 1(1)\end{array}$} & \multicolumn{2}{|c|}{$\begin{array}{l}\text { When it reaches } \\
\text { the age of } 1(2)\end{array}$} & \multicolumn{2}{|c|}{$\begin{array}{l}\text { When it reaches } \\
\text { the age of } 2(3)\end{array}$} & \multicolumn{2}{|c|}{$\begin{array}{l}\text { When it reaches } \\
\text { the age of } 3(4)\end{array}$} & \multicolumn{2}{|c|}{$\begin{array}{l}\text { When the child is in } \\
\text { pain or has caries (5) }\end{array}$} \\
\hline $\mathrm{n}$ & $\%+/-\mathrm{sp}$ & $\mathrm{n}$ & $\%+/-\mathrm{sp}$ & $\mathrm{n}$ & $\%+/-\mathrm{sp}$ & $\mathrm{n}$ & $\%+/-\mathrm{sp}$ & $\mathrm{n}$ & $\%+/-\mathrm{sp}$ \\
\hline 2 & $2.22+/-1.55$ & 58 & $64.44+/-5.05$ & 18 & $20.00+/-4.22$ & 7 & $7.78+/-2.82$ & 5 & $5.56+/-2.41$ \\
\hline \multicolumn{10}{|c|}{$\begin{array}{l}\mathrm{T}_{1,2}=3.04, \mathrm{p}_{1,2}<0.05, \mathrm{~T}_{1,3}=3.96, \mathrm{p}_{1,3}<0.05, \mathrm{~T}_{1,4}=1.72, \mathrm{p}_{1,4}>0.05, \mathrm{~T}_{1,5}=1.16, \mathrm{p}_{1,5}>0.05 \mathrm{~T}_{2,3}=3.13, \mathrm{p}_{2,3}<0.05 \\
\mathrm{~T}_{2,4}=2.04, \mathrm{p}_{2,4}<0.05, \mathrm{~T}_{2,5}=3.13, \mathrm{p}_{2,5}<0.05, \mathrm{~T}_{3,4}=1.54, \mathrm{p}_{3,4}>0.05, \mathrm{~T}_{3,5}=0.68, \mathrm{p}_{3,5}>0.05, \mathrm{~T}_{4,5}=1.83, \mathrm{p}_{4,5}>0.05\end{array}$} \\
\hline
\end{tabular}

From the answers provided, we have established that $64 \%$ have taken to heart and share the recommendation that the first visit to the dentist should take place when the child is 1 year old - the differences to the other answers are sta- tistically significant $(\mathrm{p}<0.05)$. Only $5 \%$ of mothers believe that they should take their child to the dentist when the child is in pain or has any other oral problem.

Table 6. Relative share of the answers to Question 12 given by the mothers from the experimental group

\begin{tabular}{|c|c|c|c|c|}
\hline \multicolumn{5}{|c|}{ Do you believe that our special website is useful and did you receive any new information? } \\
\hline & Yes & & No & t-test \\
\hline $\mathrm{n}$ & $\%+/-\mathrm{sp}$ & $\mathrm{n}$ & $\%+/-\mathrm{sp}$ & \multirow[b]{2}{*}{$\mathrm{T}=26.03, \mathrm{p}<0.05$} \\
\hline 85 & $94.44+/-2.41$ & 5 & $5.56+/-2.41$ & \\
\hline
\end{tabular}

The results show that almost $95 \%$ of mothers have stated that the materials available through the Dental Home program have improved their knowledge of oral health care and prophylaxis of children.

\section{DISCUSSION:}

Contemporary child oral health literature underlines the importance of parents and caregivers for the health and prophylaxis of oral diseases $[10,11,12]$. There are substantial evidence and a strong correlation between health literacy and knowledge of parents and health in early childhood. Abduljalil et al. established that mothers with a higher level of education had better knowledge of oral health and practice and that this group of mothers played a major role in their children developing healthy teeth [1]. According to a study published by Doychinova et al., the low level of oral health literacy of parents of children aged 6 to 10 is a strong contributing factor to the caries status of their children [13].

A study conducted in 2008 established that early anticipatory guidance led to a significantly lower incidence of ECC [14]. According to the results, good oral health persisted even after the child reached the age of 6 . The effect of the early training of mothers could be so strong that the positive effect on caries reduction may persist for many years ahead [15]. In 2009, a study of 460 mothers of children aged 6 to 18 months was conducted in India. The mothers were divided into three groups, each comprising 160 women. The women in groups A and B were taught appropriate feeding and oral hygiene through different motivational and educational materials, and the remaining women were the control group C. Eight months into the study, the researchers found caries in $23 \%$ of the children to the mothers in group $\mathrm{C}$ as compared to $9 \%$ and
$14 \%$ of the mothers in groups A and B [16].

Different education methods can be used - workshops, talks, leaflets, video materials, etc. [17]. We offer a web-based training platform because the internet is the most widely used communication tool between people nowadays. A survey on Twitter in 2016 identified 2652 users of the platform who were seeking information about oral health. The data showed that support is necessary to enhance the content of the information available on social media to improve its quality and reliability [18]. A pilot study of the effectiveness of the three main social networks (Twitter, Facebook, and YouTube) as an assistive training tool concerning children's oral health showed that the platforms could be effectively used for oral health promotion among children [19]. In Iran, a study was conducted to test the effectiveness of a theoretical educational program, which used the online platform Telegram [20]. The results show that this type of health education leads to better oral hygiene and awareness of oral health. Social media and the internet create new opportunities in contemporary healthcare. These social networks can make health information available to a much greater number of people than traditional media ever could. Our survey results show that the awareness of mothers of (1) fluoride prevention, (2) the risks of nighttime bottle feeding over a prolonged period, (3) mistakes in diet, and (4) the early transmission of cariogenic bacteria increased significantly compared to the mothers who did not visit www. dentalendom.bg $(\mathrm{p}<0.05)$.

Data analysis shows that a very small share of the women received oral health advice during their pregnancy. It is important that information about early visits to dental physicians reaches all pregnant women and mothers of young children. Several clinicians believe that one of 
the main strategies for caries prevention in early childhood is the training of pregnant women and the mothers/ parents of young children on the importance of appropriate diet, oral hygiene, and behavioral habits in raising infants and young children [4]. There is a need to promote the idea among gynecologists, obstetricians, pediatricians, and dental practitioners so that pregnant women and the mothers of the youngest children can be referred to a dentist who can provide adequate early oral healthcare.

The knowledge of a significant number of mothers from the experimental group of the risk of long-term nighttime bottle feeding improved after visiting our website. We believe that healthcare professionals around the young mother should consider the content of the baby formula before recommending it and also advise young mothers to discontinue nighttime feeding as soon as the first tooth erupts. Pediatricians come into contact with babies from the very first days of the newborn's life and are therefore well placed to provide advice on good oral hygiene and feeding practices to prevent ECC. Overall, the answers in both study groups reveal an adequate level of awareness that mistakes in feeding young children can be one of the risk factors for the development of caries. However, the results show that mothers do not consider breastfeeding and bottle feeding to belong to the same risk. In 2014, the UK\&I Public Health Advisory Council emphasized the importance of collaborating with families 'to establish healthier dietary patterns (including a sugar-free diet) in both general and oral health [21].

Owing to the educational program on the website www.dentalendom.bg, in addition to improving their knowledge of diet, the respondents also learned about the benefits of fluoride (the number of mothers who learned about the importance of this microelement increased by approximately $15 \%$ ).

Our recommendations about the importance of protection against early transmission of cariogenic bacteria from the mother to the baby were also positively received. The respective share of mothers who are vigilant to avoid transmitting cariogenic bacteria to their children increased threefold in the group who had access to the training material on the website $(44.44 \%$ against $16.7 \%$ in the control group). A study conducted in 2018 published data that $77.8 \%$ of the mothers did not agree that caries causing bacteria can be transmitted to their child [22]. The transmission of mutans streptococci by the mother to the child is well studied, and so is the fact that the risk of a young child developing caries increases when the level of mutans streptococci in the mother's saliva is higher. Most mothers (64.4\%) did not know that they can trans- mit caries causing bacteria to their children. This finding is consistent with the results of other studies.

An article published in recent years has shown that $3 / 4$ of mothers do not believe that breastfeeding can cause caries [22]. Furthermore, most mothers in the control group of our study (62.27\%) also believed that long-term nighttime breastfeeding and allowing the child to fall asleep on the breast did not carry a risk of developing ECC. We believe that given the benefits of breastfeeding, it should be undoubtedly promoted, but that at the same time, dental physicians, pediatricians, and the entire medical team around the young mother should promote adequate oral hygiene after each meal and inform the parents that long-term (after the child's first birthday) nighttime feeding can cause caries.

Knowledge of ECC was registered among approximately $36 \%$ of the mothers who visited the educational program as compared to $21 \%$ of mothers who did not have advanced information. The difference is statistically significant and shows an increase of $15 \%$. Despite this, the share of mothers with adequate knowledge remains unsatisfactory, hence the need to also enhance the education of mothers verbally. The share of mothers in the control group who were not familiar with the risk of ECC was high $(79 \%)$. This warrants the conclusion that society should be better informed of the disease and the risk factors that can cause it.

Our study shows that more than $60 \%$ of the mothers positively received the idea that the first visit of the child to a dentist should be around the first birthday. AAPD recommends that the first examination takes place within 6 months of the first tooth eruption and no later than the child's first birthday. This overlaps with our own recommendations. Our advice to all mothers is to visit a dental physician in the first year of the child's life and adopt the practice of visiting à Dental Home with each newly erupted tooth.

\section{CONCLUSION:}

The study demonstrates significantly improved awareness and knowledge of the mothers after visiting our website dedicated to the "Dental Home for Children" program. This, along with the fact that $95 \%$ of respondents state that our website was useful to them and helped them gain new knowledge, confirms that research hypothesis. The obtained positive results give us reason to believe that e-learning health education programs are useful for both mothers and children aged up to 3 years. The program is easily available to the public and can be considered as a form of health promotion. 
REFERENCES:

1. Abduljalil HS, Abuaffan AH. Knowledge and practice of mothers in relation to dental health preschool children. Adv Genet Eng. 2016; 5(2): 1-7. [Crossref]

2. Gomes APM, da Silva EG, Goncalves SHF, Huhtala MFRL, Martinho FC, de Paiva Goncalves SE, et al. Relationship between patient's education level and knowledge on oral health preventive measures. Int Dent Med J Adv Res 2015; 1(1):1-7.

3. Anil S, Anand PS. Early Childhood Caries: Prevalence, Risk Factors, and Prevention. Front Pediatr. 2017 Jul 18;5:157. [PubMed]

4. American Academy of Pediatric Dentistry. Policy on early childhood caries (ECC): Classifications, consequences, and preventive strategies. The Reference Manual of Pediatric Dentistry. Chicago, Ill.: American Academy of Pediatric Dentistry. 2020: 79-81. [Internet]

5. Girish Babu KL, Doddamani GM. Dental home: Patient centered dentistry. J Int Soc Prev Community Dent. 2012 Jan;2(1):8-12. [PubMed]

6. Nourijelyani K, Yekaninejad MS, Eshraghian MR, Mohammad K, Rahimi Foroushani A, Pakpour A. The influence of mothers' lifestyle and health behavior on their children: an exploration for oral health. Iran Red Crescent Med J. 2014 Feb;16(2): e16051. [PubMed]

7. Al-Zahrani AM, Al-Mushayt AS, Otaibi MF, Wyne AH. Knowledge and attitude of Saudi mothers towards their preschool children's oral health. Pak $J$ Med Sci. 2014 Jul;30(4):720-4. [PubMed]

8. [Dental Home for Children. Ques- tionnaire] [in Bulgarian] [Internet]

9. Guideline: Protecting, Promoting and Supporting Breastfeeding in Facilities Providing Maternity and Newborn Services. World Health Organization. 2017. 120 p. [nternet]

10. Schroth RJ, Brothwell DJ, Moffatt ME. Caregiver knowledge and attitudes of preschool oral health and early childhood caries (ECC). Int J Circumpolar Health. 2007 Apr;66(2): 153-67. [PubMed]

11. Saied-Moallemi Z, Virtanen JI, Ghofranipour F, Murtomaa H. Influence of mothers' oral health knowledge and attitudes on theirchildren's dental health. Eur Arch Paediatr Dent. 2008 Jun;9(2):79-83. [PubMed]

12. Chan SC, Tsai JS, King NM. Feeding and oral hygiene habits of preschool children in Hong Kong and their caregivers' dental knowledge and attitudes. Int J Paediatr Dent. 2002 Sep;12(5):322-31. [PubMed]

13. Stanev N, Doichinova L, Andreeva-Borisova R. The Role of Parents Health Literacy For The Development Of Dental Caries In Children. MedInform 2020; 7(2):1190-1197. [Crossref]

14. Plutzer K, Spencer AJ. Efficacy of an oral health promotion intervention in the prevention of early childhood caries. Community Dent Oral Epidemiol. 2008 Aug;36(4):335-46. [PubMed]

15. Plutzer K, Spencer AJ, Keirse MJ. Reassessment at 6-7 years of age of a randomized controlled trial initiated before birth to prevent early childhood caries. Community Dent Oral Epidemiol. 2012 Apr;40(2):116-24. [PubMed]
16. Manchanda K, Sampath N, Sarkar AD. Evaluating the effectiveness of oral health education program among mothers with 6-18 months children in prevention of early childhood caries. Contemp Clin Dent. 2014 Oct;5(4):478-83. [PubMed]

17. Macintosh AC, Schroth RJ, Edwards J, Harms L, Mellon B, Moffatt M. The impact of community workshops on improving early childhood oral health knowledge. Pediatr Dent. 2010 Mar-Apr;32(2):110-7. [PubMed]

18. Almaiman S, Bahkali S, Alabdulatif N, Bahkaly A, Al-Surimi K, Househ M. Promoting Oral Health Using Social Media Platforms: Seeking Arabic Online Oral Health Related Information (OHRI). Stud Health Technol Inform. 2016; 226:283-6. [PubMed]

19. Tse CK, Bridges SM, Srinivasan DP, Cheng BS. Social media in adolescent health literacy education: a pilot study. JMIR Res Protoc. 2015 Mar 9;4(1):e18. [PubMed]

20. Scheerman JFM, Hamilton K, Sharif MO, Lindmark U, Pakpour AH. A theory-based intervention delivered by an online social media platform to promote oral health among Iranian adolescents: a cluster randomized controlled trial. Psychol Health. 2020 Apr;35(4):449-466. [PubMed]

21. NICE Guideline. Oral health: local Authorities and Partners. Public health guideline. NICE. 22 October 2014. 77 p. [Internet]

22. S Dhull K, Dutta B, M Devraj I, Samir PV. Knowledge, Attitude, and Practice of Mothers towards Infant Oral Healthcare. Int J Clin Pediatr Dent. 2018 Sep-Oct;11(5):435-439. [PubMed]

Please cite this article as: Bogovska-Gigova R, Kabaktchieva R. Mothers' Knowledge towards Oral Health of Children aged up to 3 years before and after Educational Program. J of IMAB. 2021 Oct-Dec;27(4):4052-4059.

DOI: https://doi.org/10.5272/jimab.2021274.4052

Received: 31/03/2021; Published online: 22/10/2021

Address of correspondence:

Ralitsa Bogovska-Gigova

Department of Pediatric Dentistry, Faculty of dental medicine, Medical University - Sofia,

1, Georgi Sofiisky str., Sofia, Bulgaria.

E-mail: r.bogovska@fdm.mu-sofia.com, 